\title{
English Language Training Programme for Indonesian Toursim Drivers: A Report on South Sulawesi Language Teaching in Makassar
}

\author{
Burhanuddin \\ burhanuddin.burhanuddin@umi.ac.id \\ Akademi Bahasa Asing UMI \\ Ratnawati \\ ratnawati.ratnawati@umi.ac.id \\ Akademi Bahasa Asing UMI \\ Andi Hudriati \\ andi.hudriati@umi.ac.id \\ Universitas Muslim Indonesia
}

\begin{abstract}
Training on the Use of Basic English for tourism drivers in South Sulawesi aims to improve English language skills for each trainee. This is relevant to tourism development which is one of the development sectors currently being promoted by the government. South Sulawesi has various tourism potentials, including natural and cultural attractions. More and more foreign tourists visit this area and they are guests who must be served well, therefore participants must be able to communicate in English with the tourists, so that tourists feel happy, but the fact is that there are still many tourism drivers who cannot communicate in English and they only use gestures, even though they have a big share and contribution to the development of tourism. During the English training, the participants were stimulated using lectures, role plays, question and answer and demonstrations. Training activities for tourism drivers are carried out for 2 and a half months. The English materials provided include various conversations and vocabulary which include: Alphabet, Parts of Speech, Countries \& Nationalities, at the hotel, at the bank / money changer, places \& direction, at the post office, at the tourist objects and so on. This training also produces training modules that are printed and distributed to all participants. Although it is still in simple form, it is hoped that this module will be useful for further training. This community service activity can be concluded that it has been successfully implemented, this is evidenced by the suitability of the material with the needs, active participation and high motivation of the participants who are expected to provide maximum service and indirectly introduce and promote tourism potential in South Sulawesi, according to With the target to be achieved from this training, determine the quality of public transportation services through tourism drivers so that they can have intensive conversations with both domestic and foreign tourists.
\end{abstract}

Keywords: English Language Training, Tourism Drivers, ELT 


\section{INTRODUCTION}

The tourism sector is a sector that contributes a lot of foreign exchange to the State after oil and gas. The development of tourism from year to year continues to grow rapidly after the government declared the "Visit Indonesia Year 1991" the development of world tourism and Indonesia was followed by the development of the social and economic structure of the world community and Indonesia. The more people who have the higher income. Tourism has developed into a global phenomenon, a basic necessity, and a part of human rights that must be respected and protected.

According to the Indonesian Law No.10 of 2009 concerning tourism, the government and local governments, the business world, and the community are obliged to ensure that travel as the right of everyone can be upheld so as to support the achievement of increased human dignity, increased welfare, and friendship between nations in the context of realizing world peace. The population is one of the main capital in the development of tourism at present and in the future because it has a dual function, in addition to being a potential source of domestic tourists. Tourism can be used as a means to create awareness of national identity and togetherness in diversity.

Whereas the condition of nature, flora and fauna as reliable potentials, as well as ancient relics, historical, artistic and cultural heritage owned by our nation are resources and capital for tourism development to increase the prosperity and welfare of the people. The freedom to travel and take advantage of free time in the form of traveling is part of human rights. Tourism is an integral part of national development which is carried out in a systematic, planned, integrated, sustainable and responsible manner while still providing protection for religious, cultural values that live in society, sustainability and the quality of the environment in society.

Indonesia is a tourist destination country in Southeast Asia with abundant natural wealth, various ethnicities, cultures, languages, religions, and home industries, making it a country that is widely glimpsed and visited by foreign tourists, especially European countries. European countries that like nature tourism, culture, adventurers, and special interests such as bird watching, trekking, diving and others. Indonesia is also rich in culinary tourism with various or various culinary delights from various regions that are in great demand by Asian and European and American tourists, making it one of the countries with culinary tourism destinations. Halal tourism also continues to be encouraged considering that Indonesia is the largest Muslim country and to attract tourists from Muslim countries and the Middle East. The tourism sector is a sector that synergizes a lot with other sectors, such as agriculture, fisheries, home and creative industries, transportation, hospitality industry such as hotels and so on.

Tourism also has major supporting organizations such as; Association of Indonesian Tour and Travel Agency (ASITA), Indonesian Hotel and Restaurant Association (PHRI), Indonesian Tour Guide Association (HPI), Association of Maritime and Tirta Tourism Entrepreneurs (GAWAHISTRI), Indonesian Congress and Convention (INCCA), Indonesian Exhibition Entrepreneurs Association ( ASPERAPI), Indonesian Recreation Park Business Association (PUTRI), Inbound Tours Operator Club (ITOC), Indonesian Air Carrier Association (IACA) and others. 
South Sulawesi is one of the tourist destinations in Indonesia with potential market resources for European and Asian tourists. Toraja is a tourist destination (DTW) that is included in the top ten DTW in Indonesia. Apart from Toraja, South Sulawesi also has other interesting natural attractions such as Bantimurung, Bira Beach, Leang-leang Caves, Rammang-rammang Karst Park, Tempe Lake, and marine tourism with white sandy islands. International tourists can spend an average of 4 days 3 nights, 5 days 4 nights, even a week with round trip Makassar-Bugis-Toraja tours.

One of the sectors and services used by tourists is the transportation sector. Transportation is usually owned by tour and travel entrepreneurs or especially rental entrepreneurs in the city of Makassar. They certainly employ participants or drivers. These participants are covered by a forum called the Indonesian Tourism Participants Association or ASPI. These tourism or travel participants work as free lance and pay roll. Freelance is they work as freelance participants who can be employed by several travel and rental companies. Meanwhile, Pay roll is a participant who is employed as a participant or permanent employee by a travel or rental company.

Participants in carrying out their duties are usually accompanied by a tour guide or guide who certainly helps them in carrying out their duties as participants. However, not a few foreign tourists only use transport services with a driver or participant. These participants who have the highest level of education are high school graduates (SMA) or the equivalent. Even those with reading capital can finally get a driver's license. A participant's tour is not as easy as if accompanied by a tour guide or guide, they only focus on obstacles and even tour activities are not smooth and often get complaints, so they really need foreign language communication that at least can be understood by guests or tourists. In facilitating the tasks of tourism participants, they require foreign language communication, namely English. Sometimes they also want courses but are shy and do not have enough funds.

Based on the description above, the Training implementation team required us to look at them as tourism participants in South Sulawesi, especially those living in the city of Makassar to get training and additional knowledge from us, especially basic conversations in English according to their daily needs. Our hope is that even this training can be sustainable in order to support and empower the community, namely tourism communities who have tourism-minded or tourism awareness. With the theme "Basic English Training for South Sulawesi Tourism Drivers in Makassar".

\section{METHOD}

This study employs action research as the approach. The Action Research serves to conducting research to help organizations bring about positive, sustainable change (Lewin, 1930). Extensive language training will be conducted for the tourist drivers in Makassar. Initially, observation was used as an introductory stage to determine the extent of the drivers's understanding of English before the training is held. Then, the lecture method is used to present material or information orally, both formally and informally. Additionally, the Problem-Solving method is used to train driverss to face various problems to be solved individually or collectively. And Finally, demonstration or role play was conducted, this method 
is used in the form of interactive dialogue and role playing both indoors and outdoors with the aim that participants could speak directly with foreign tourists.

The stages of the study to be carried out were:

\section{Introduction}

At this introductory stage, the implementation team carried out preliminary observations to get a picture of the real conditions in the field and the needs during the English training.

\section{Training}

The tutors carried out this activity for almost 3 months involving 30 participants, all of whom were members of the Indonesian Tourism Participants Association (ASPI). During the training, the drivers are taught how to communicate using basic English. The training is not specifically focused on general English, but they are also introduced to English that is relevant to tourism and their profession which always interacts with tourists such as examples of conversations between front officers and tourists, examples of conversations between waiters and customers, drivers and tourists at the bank / money changer, places \& direction, at the tourist objects and so on.

\section{Evaluation}

Evaluation is carried out after driverss understand the training material. The assessment for each drivers is based on activeness during the training.

\section{Review}

After the evaluation is held, it is hoped that driverss can have intensive conversations with foreign tourists and not forget what they have gained during the training process.

\section{The Drivers' Activities}

The Association of Indonesian Tourism Participants in South Sulawesi is an association that fosters tourism participants who are driverss in the implementation of the Training program located in the city of Makassar, which is about $5.1 \mathrm{KM}$ from the location of the Indonesian Muslim University College. The drivers's location which is near the highway can be accessed easily. The location is not far from the city center, making it easier for English language training to be carried out.

This association has dozens of participants and 30 participants are registered to take part in this activity and the main target in this activity is to provide basic English language training for tourism drivers according to the targets to be achieved in this training.

Currently this tourism driver association is still focused on activities taking foreign and domestic tourists so when the tutors expressed their desire to hold this Training activity, they were very enthusiastic and enthusiastic about participating in this training and even we as a tutors really appreciate them with their tenacity participate in this activity, even though the original target of the tutors was only to provide 12 meetings but the realization was up to 20 meetings. 


\section{FINDINGS AND DISCUSSION}

Basic English training can encourage motivation in using English as a communication tool. This is shown by being more enthusiastic and motivated and participating actively in every activity carried out.

\section{First Meeting}

The first meeting was held on Friday, August 7, 2020 at the tutors's house at 16.00-17.00. The implementation of this service was attended by 30 participants, this meeting began with explaining the objectives of community service activities. This is one of the lecturers' duties which is one of the Tri Darma Perguruan Tinggi.

The implementation of this service activity begins with introducing each other to find out the skills and interests of driverss in communicating before the actual material is applied. After that, the tutors presented the first topic, namely the alphabet by explaining what is meant by the alphabet and the driverss happily followed what was said by the tutors so that the driverss were able to pronounce and distinguish vowels and consonants in English.

\section{Second Meeting}

The topic given at the second meeting which was precisely held on Sunday, August 11, 2020 at 16.00-18.00 was Part of Speech. Activities in this second meeting focused on providing part of speech material which is the most basic material which is very important to learn. Nothing but the purpose of learning part of speech is to make it easier for us to learn other materials of a higher level, after that we as the tutors provide an explanation of the parts that fall into the Part of Speech category and more detailed examples that are linked to the reality of the participant's life. training. The method used in the second meeting was lecture and question and answer methods.

The results of the training at the second meeting showed that the drivers had great motivation and interest in participating in the training and advice was seen from their responses and participation during the training process.

\section{Third Meeting}

On Thursday, August 13, 2020, the topics given at this training were to Be and to Have, which was attended by 12 participants, the methods used were demonstrations or conversations. Alhamdulillah, the driverss were able to understand the material comprehensively and the indicator of success was that they could communicate in English. Participants are very active because they often face the material presented in their daily work, namely welcoming guests from various countries and they must use English in communicating with tourists visiting Makassar and the participants are very enthusiastic about having face to face conversations.

Have, has, and had are primary auxiliary verbs, primary auxiliary verbs are auxiliary verbs that have no meaning but help in the formation of tense characters. 


\section{Fourth Meeting}

The topic given at the fourth meeting was To do \& Modals, precisely on August 16, 2019. The tutors provided material by explaining the urgency of To Do and Modals or often known as Secondary Auxiliary Verbs, which are auxiliary verbs that give additional meaning to Main Verbs in sentences. Its function is to express willingness or ability, necessity and possibility. The presentation of the material using audio-visual media made the participants focus on the material and pay close attention to the video and did not make them bored.

Furthermore, at the end of the meeting the participants enjoyed themselves very much, even they were very enthusiastic and the atmosphere became rowdy because they wanted to perform a role play based on the conversation topics they had broadcast through audio-visuals.

\section{Fifth Meeting}

On Monday, August 20, 2020, the tutors provided material on the topic Questions Words \& Miscellaneous. The method used is still the same, namely role play with the implementation of authentic material to the participants. However, the difference is that this material is given outdoors to avoid boredom from the participants. It is also fun to see them talking even though there are some who still mispronounce, for example the question word who they call ho because they do this by using the dctation technique which has to look at the card stuck on the blackboard then they run around and whisper the words listed on the card so as not to be heard from the rest of the group. On this occasion, the atmosphere was more exciting and livelier because the organization was carried out by members of the tutors and in the end they had the conversation face to face with tourists after practicing their fellow participants. In this game all participants were active because they had their share in question and answer.

\section{Sixth Meeting}

On Thursday, August 27, 2020, the tutors provided material on the topic of Numeral. At the beginning of the training discussed several English games about numbers (number games). This number game contains several games which are of course to help participants to practice pronouncing numbers from one to the next and also to train participants in counting, of course, using English which is certainly in a way that can entertain the training participants. And the name of the game is Take a number.

- Purpose: to train participants' listening skills and test their ability to follow directions.

- Language level: all

- Equipment and materials: paper and pencils

The Number game presents a much more challenging game. This number game is very easy to apply on several occasions. The game starts with the servant saying, "Take a number", and participants are asked to write the number up to the participant himself, for example the first participant writes the number 3 on his / her paper. Then the tutors 
continued by saying "plus eight", the participants had to add the number 8 to the number they took. The tutors can also say "Minus___, "Devided by__ " or "Multiplied by__. When finished, participants are asked to collect paper containing addition, subtraction, division and multiplication. Participants who add up correctly will get a reward and participants who are wrong will get punishment.

Example:

Take a number $\quad: 3$

Plus $8 \quad: 11$

Minus $7 \quad: 4$

Divided by $2 \quad: 2$

Multiplied by $6 \quad: 12$.

After giving the game above, the core material about numerals is presented and given the opportunity to talk about numbers.

\section{Seventh Meeting}

On Thursday 27 August 2020, Days, Months and Years were provided as the material. The tutor provides an explanation of each of the uses of the topic. The tutor explained the following:

- Day to retrieve the number of days in months from a number of dates, which is a number whose value will range from 1 to 31 . The date number is the serial number of the date which will be displayed in the form of a date display if the 'Date' format is applied to it.

- $\quad$ Month function is used to take the number of months in a year from a Number of Dates, which ranges from 1 for January to 12 for December.

- $\quad$ Year Function used to take the number of years from a number of dates.

After being given the training the participants had face to face conversations to measure the extent to which the participants understood and their interest in understanding the material that had been given, at the end of the training the participants listened to a song about the topic and they were very happy with the singing of the song as well.

\section{Eighth Meeting}

On Thursday, August 30, 2020 is an English training with the topic Time. The method used is discussion and focuses on student centered learning. The tutors previously showed the props that wrote the time of the words and instructed the participants to write the word travel, then he said that the first letter (t) represents the hour and the last letter (1) represents the minute. This means showing the time of twenty five to ten, the participants are formed into 4 groups and the cross-checking team will re-check their work, although there are some who still find it difficult to distinguish the telling time between British and American styles. But after being 
given directions and explanations in detail they were able to have a conversation using their time well.

\section{Ninth Meeting}

The topic given at the ninth meeting, to be precise on September 3, 2020, namely Countries $\&$ Nationalities, in our opinion as a team of service providers, this material is very important and interesting for them to understand because it is relevant to the country and nationality which sometimes often causes difficulties for someone to distinguish the name of the country, the nature and the name of the nation of a country. later it will be used by participants to communicate with foreign tourists. Therefore, to avoid misinterpretation, it is necessary to provide a more comprehensive explanation to the participants, for example the words English and English, Belgian and Belgian, or Indonesian and Indonesian? England is the name of the country, while English is things related to England, for example English; English and English schools; English school. While the name of the people is British / English and the name of the population is Englishman / Englishwoman. To talk about the number of a population / person we simply add the 's' for example;

a. One belgian

b. Two belgians

c. Three belgians

Based on the results of the training, there was a significant progress towards the material given to the participants.

\section{Tenth Meeting}

The topics were presented to participants at the tenth meeting to be precise on September 6, 2020 with the Basic Question material. This material is still ongoing with the question word material or the fifth meeting. In this activity, we as the tutors provide some examples of the most frequently used questions for communication between tourism participants and tourists using demonstration methods and role-play.

\section{Eleventh Meeting}

At the tenth meeting on September 10, 2020, the topic presented to participants was at the airport. The lecture method is used to provide an explanation and understanding in detail. This material is very important to be presented to the participants because the airport is the first place if we visit a foreign country. In this regard, it is necessary for them to know the meaning of the symbols at the airport and then apply some vocabulary to simple conversations by means of work pairs, including: 
A. During check-in:

May I see your passport, please? - Bolehkah saya melihat paspor Anda?

Here is my passport / Here it is. - Inilah paspor saya.

Would you prefer a window or aisle seat? - Apakah Anda lebih memilih kursi di dekat jendela atau di dekat lorong?

A window seat, please. - Tempat duduk di dekat jendela.

B. At the immigration office:

What's the purpose of your visit? - Apakah tujuan dari kunjungan Anda?

Do you have a return ticket to $\times \times$ ? - Apakah anda memiliki tiket pulang ke $\mathrm{xx}$ ?

How long will you be staying in $\times \times$ ? - Berapa lama Anda akan tinggai di $\mathrm{xx}$ ?

Where are you staying? - Di mana Anda tinggal?

C. Upon arrival:

Where can I get my baggage? - Di mana saya bisa mengambil koper saya?

Where is the tourist information? - Di manakah tempat informasi turis?

Is there an airport shuttle to the city center? - Apakah ada bus antar jemput dari bandara ke pusat kota?

\section{Twelfth Meeting}

At the eleventh meeting on September 13, 2020, the topic presented at this training was at the hotel which was explained by the tutors, participants were very enthusiastic about the material provided because they immediately practiced the conversation directly by playing the role given at the hotel. Participants are very motivated and participate actively by speaking according to the given scenario, but first the participants memorize the useful vocabularies found on page 17 in the training module which has been distributed to each training participant. The number who attended the twelfth meeting was ....... people.

\section{Thirteenth and Fourteenth Meeting}

On September 17, 2020, the material presented by the tutors was on the telephone. The method implemented is question and answer and role play, while the topic is presented in authentic material because it is directly practiced via telephone between participants and tourists. Although, at the beginning of the meeting they were instructed to watch a video conversation conducted by two people who were communicating by telephone that was broadcast via the LCD. Furthermore, 
they were asked to provide comments regarding the telephone conversation they had just watched. Additional material provided at the fourteenth meeting was telephone analogy. The purpose of this study is to find out the abbreviations or abbreviations that are relevant to telephone analogy.

\section{Fifteenth Meeting}

On September 20, 2020, the material presented by the tutors is in the restaurant. The method implemented is question and answer and role play, simple conversations are used in restaurants between waiters, tourists and participants, namely starting by describing the dining experience at the restaurant, informing sources of inspiration for dishes, or highlighting typical restaurant dishes. The purpose of knowing this is so that tourists know the special foods of each region visited through the conversation. And at the end of the meeting the tutors provides a riddle (riddle) to provide inspiration for the participants to compete to find answers to the symbols given. The symbol of the puzzle is 1004180 and the tutors gives a clue and thank God there is a participant who is able to answer the puzzle by giving the correct answer, namely I owe nothing for I ate nothing (I don't owe because I don't want anything). And as a reward the tutors gave gifts to these participants.

\section{Sixteenth Meeting}

The sixteenth meeting was held on Friday 27 September 2020. This service was attended by 30 participants with the topic of training, namely Places and Direction. On this occasion the training participants showed enthusiasm when asked to present the tour itinerary and map they made in groups. Making plans or travel directions in English is very important to learn. Tourists who visit tourism objects need detailed information on each place and tourism object they visit. This is because the tour itinerary contains detailed information about the time and place (time and place to be visited). Therefore, training participants are provided with knowledge regarding Places and Directions in detail.

\section{Seventeenth Meeting}

The seventeenth meeting was held on Thursday, October 1, 2020, the tutors provided material on the topic of Shopping. This material was also greatly responded to by the training participants because it was related to shopping, therefore the tutors presented the material in the form of PowerPoint and used audio-visual (video) that was broadcast. Participants are instructed to watch videos about shopping which include material on the use of how much and how many and other vocabularies relevant to shopping, for example fixed prices, small changes, and so on. The participants paid close attention to the video and how to pronounce the vocabulary relevant to the item and price. Then the next day the tutors and participants practiced the conversation directly at the Mall (authentic material).

\section{Eighteenth Meeting}

The tutor team carried out training activities on Thursday, October 4, 2020 with the topic at the Tourist Objects. This material is given to introduce participants to tourism objects in English and discuss tourism objects that require participants to get to know more closely the natural wealth found in South Sulawesi. Not only knowing the tourism objects in Makassar as the capital, but there are many benefits that can be obtained because participants are invited to 
dig up information from the many interesting tourist objects scattered in South Sulawesi. This is in line with and attached to one of the character education contents in the 2013 Curriculum, namely love for the country. One indicator of the value of the character of love for the country that can be done by participants is to provide information, both from printed and electronic sources, regarding the natural and cultural wealth in Indonesia (Nurohmah, 2016: 41). Thus, participants are not merely training themselves to use English in the tourism sector. However, there are efforts to instill positive character values obtained through this activity.

\section{Nineteenth Meeting}

The nineteenth meeting was held on Thursday, October 8, 2020 with material at the Bank / Money Changer. The tutors prepare material that has been prepared beforehand and prepares several tools such as money from several countries that must be prepared and provide useful vocabularies such as the word interest which can mean interest and can also mean interest, this needs to be given a more detailed explanation with the aim of knowing the participants' understanding regarding expressions used in inquiring and notifying about activities taking place at the bank or which are relevant to money changers and it makes it easier for them to understand the material given because it is presented authentically.

\section{Twentieth Meeting}

The last meeting was held on Thursday, October 11, 2020 with material at the Post Office. The implementation team prepares material that has been formulated in such a way as to provide useful vocabularies that are relevant to activities at the post office, for example air mail, registered mail, mail boxes, business letters, friendly letters and many other words that they practice in the form of conversations so that more accustomed to practicing speaking skills in English.

\section{CONCLUSION}

Based on the explanation above, the following conclusions can be drawn. First, the participation of driverss during basic English training for South Sulawesi tourism drivers can be seen that it has brought great benefits to each participant, through this training activity they already have the vocabulary to be used in speaking or communicating basic English related to developing potential. a tourism driver using authentic learning resources. Second, the use of audio-visual media (video) in the training can increase the participants' motivation and interest during the training and is also very good for introducing English in a way that is not boring. This can be seen from the very significant results that are increasing at each meeting. In addition, enthusiasm and enthusiasm were evident during the English training process.

\section{ACKNOWLEDGEMENTS}

Thank you to the Community Service Institute (LPkM) of Universitas Muslim Indonesia for funding this service activity. Much appreciation also to the ranks of the South Sulawesi 
Indonesian Tourism Drivers Association (ASPI) South Sulawesi as driverss in the service activities of Basic English Training for South Sulawesi Indonesian Tourism Drivers in Makassar.

\section{REFERENCES}

Alcantud-Díaz, M., Vayá, A. R., \& Gregori-Signes, C. (2014). 'Share your experience'. Digital storytelling in English for tourism. Ibérica, Revista de la Asociación Europea de Lenguas para Fines Específicos, (27), 185-204.

Bos, L., McCabe, S., \& Johnson, S. (2015). Learning never goes on holiday: an exploration of social tourism as a context for experiential learning. Current Issues in Tourism, 18(9), 859875.

Edo-Marzá, N. (2014). A practical corpus-based approach to teaching English for tourism.

Fox, R. (2008). English in tourism: a sociolinguistic perspective. Tourism and Hospitality Management, 14(1), 13-22.

Nama Organsasi Kepariwisataan. www.kumau.info>edukasi. diakses 28 November 2016

Organisasi Kepariwisataan Nasional Indonesia. www.kanal.web.id. Manajemen. Diakses 27 November 2016

Prachanant, N. (2012). Needs analysis on English language use in tourism industry. ProcediaSocial and Behavioral Sciences, 66, 117-125.

Raţă, G. (Ed.). (2013). The English of tourism. Cambridge Scholars Publishing.

Selman, P. (1991). Tourism and the environment: a case study from Turkey. Environmentalist, 11(2), 113-129.

Simion, M. O. (2012). The importance of teaching English in the field of tourism in universities. Annals-Economy Series, 2, 152-154.

Undang-Undang Nomor 10 Tahun 2009 tentang Kepariwisataan. www. ekowisata.org. diakses 16 Januari 2009.

Zahedpisheh, N., Bakar, A., Zulqarnain, B., \& Saffari, N. (2017). English for Tourism and Hospitality Purposes (ETP). English Language Teaching, 10(9), 86-94. 